\section{ZIRKELITE-A QUESTION OF PRIORITY.}

IN the Mineralogical Magazine, Vol. XI., pp. 86-88 (read June 18, 1895) is described a new mineral containing zirconium, titanium, lime, iron, etc., under the name of Zirkelite. This paper was prepared by my friend Dr. E. Hussak and Mr. G. T. Prior.

Later Mr. Prior (1. c., pp. 180-183, Read Nov. $17,1896)$ published an analysis of the same mineral.

I wish to protest against the use of the name Zirkelite for this mineral on the ground of the prior use of it to designate a commonly occurring rock belonging to the basaltic family.

When two subjects are so intimately connected as mineralogy and petrography it does not seem to be for the interest of science that names should be duplicated in them. So true is this that I abandoned the name Rosenbuschite, which I had given to a class of rocks in honor of Professor Rosenbusch, because only a few weeks previously it had been employed to designate a new mineral.

The term Zirkelite was used by me in 1887, or seven years before it was taken by Messrs. Hussak and Prior. (See Preliminary Description of the Perioditites, Gabbros, Diabases and Andesites of Minnesota. Bulletin No. 2; Geological Survey of Minnesota, 1887, pp. 30-32.) It was used to designate the commonly occurring altered conditions of basaltic glassy lavas which are often called diabase glass, etc. Zirkelite occurs forming the entire mass of thin dikes, and the exterior parts of many dikes of diabase and melaphyr, as well as the surface of old lava flows like the melaphyrs and diabases of Lake Superior, Newfoundland and elsewhere. Zirkelite holds the same relation to tachylite that diabase and melaphyr do to basalt, $i$. e., an older and altered type. The macroscopic and microscopic characters of this rock were given in the locality cited above.

The term Zirkelite was again used in the same way in my Report to the Geological Survey of Michigan for 1891-1892 (1893, pp. 30, 97, 138, etc.).

It was also published in my classification of rocks given in the Catalogue of the Michigan College of Mines (Michigan Mining School) 1891-
1892, p. 104; 1892-1894, Table XI.; 1894-1896, Table XI.

Further, the term Zirkelite is defined in accordance with my usage in Loewinson-Lessing's Petrographisches Lexikon, 1893, p. 252 ; and accounts of it are given in the Neues Jahrbuch für Mineralogie, 1893, II., p. 292, and in Kemp's Handbook of Rocks, 1896, p. 170.

M. E. WADSWORTH.

Michigan College of Mines,

Houghton, Mich., December 17, 1897.

\section{SCIENTIFIC LITERATURE.}

Catalogus Mammalium tam viventium quam fossilium. Dr. E. L. Trouessart. New Ed. Fascic. II., Carnivora, Pinnipedia, Rodentia (Protrogomorpha and Sciuromorpha), pp. 219 452, June, 1897. Fascic. III., Rodentia (concluded), pp. 453-664, Oct., 1897. Berlin, R. Friedländer und Sohn. Price, $\$ 2.50$ each part.

The second and third parts of Trouessart's ' Catalogue of Mammals, living and fossil,' have come to hand and carry the work through the Carnivora and Rodentia. These parts are less satisfactory than the first, and cannot be said to represent the present state of knowledge of the groups treated, particularly with respect to American forms. Among the latter many synonyms are accorded full specific rank, many good species are degraded to synonymy, and many forms are transposed in a manner that shows an absence of appreciation of their affinities. And when it comes to the geographic distribution of American species the most astonishing inaccuracies creep in, as might be expected.

In matters of nomenclature Dr. Trouessart seems to be a law unto himself, and consistency does not seem to be one of his canons. In using Brisson he quotes the pre-Linnæan edition (1756), which has no status in nomenclature, instead of the edition of 1762 ; while in quoting Linnæus he takes the opposite course and uses the 12th edition (1766) instead of the 10th (1758), which is accepted the world over as marking the beginning of Zoological nomenclature. With respect to Brisson's genera it will be interesting to know what rules, if any, led to the adoption of Hydrochoerus and the re- 
jection of Odobænus, Glis* and others. If all had been rejected his course would have had the merit of consistency and would be defensible. The generic name Trichechus is erronously applied to the Walrus instead of the Manatee.

Dr. Trouessart is a most diligent searcher of the literature and is to be congratulated on the freedom of his catalogue from omissions. Most of the errors here pointed out are such as are bound to creep in in an undertaking of this character and magnitude, and the reviewer wishes it understood that in calling attention to them he has not done so in a spirit of criticism, but for the purpose of rendering the work more useful.

The authority for the generic name Bassariscus is Coues, 1887, not 'Rhoads, 1894.' The genus Wagneria Jentink, 1886, cannot stand. It is not only the same as Bassariscus, but is preoccupied.

Thalassarctos Gray, 1825, is antedated by Thalarctos of the same author and based on the same animal.

Lyncus Gray, 1825 (first printed Lynceus by Gray in 1821), is antedated by Lynx Kerr, 1792.

The name Ictis Kaup, adopted for a subgenus of Weasels, is preoccupied by Ictis Schinz, 1824, for which reason Arctogale Kaup will have to stand for the Weasels. This I have already published in Scievce (Vol. V., p. 302, Feb. 19, 1897); and since Arctogale Peters, 1864, is preoccupied by Arctogale Kaup, 1829, I proposed the new name Arctogalidia for the palm civets, of which Viverra trivirgata is the type (see SCIENCE as above).

Ursus piscator Pucheran, 1855, and $U$. beringiana Middendorff, 1851, given as forms of $U$. arctos, are based on the same animal.

Ursus emmonsi Dall, given as a 'variety' of $U$. americanus, is certainly a most distinct species.

* In the case of Glis it is stated in a footnote that the genus cannot be admitted because Linnæus had previously instituted the order Glires, and because Brisson did not use binomial nomenclature. The first reason is trivial and not in accord with any code of nomenclature; the second, if considered a valid objection by the author, should have caused him to reject Hydrochoerus also.
A most unfortunate slip is the reintroduction of Peale's generic name Cricetodipus (a synonym of Perognathus) for the Kangaroo rats of the genus Perodipus, in accordance with an ill-advised suggestion from Mr. Rhoads. But Mr. Rhoads carefully abstained from giving Peale's measurements of his type specimen, which prove beyond question that the animal could not have been a Kangaroo rat. The hind foot measured ' $\frac{8}{10}$ inch' -a trifle less than $20.5 \mathrm{~mm}$., which agrees with young specimens of Perognathus from the plains of the Columbia, in Oregon and Washington. A nursing young Kangaroo rat (Perodipus columbianus), from the same region, has a hind foot measuring $36 \mathrm{~mm}$. and a total length more than double that given by Peale for his Cricetodipus.

Among the 12 Kangaroo rats of the genus Dipodomys given full specific rank, one (similis) is a synonym (of simiolus) and three (ambiguus, simiolus and parvus) are subspecies (of merriami. Mearns). In the sequence given, these subspecies are not only accorded specific rank, but with one exception are removed from the forms to which they are most closely related and placed after members of widely different groups. Similarly, the large Dipodomys spectabilis, with its long tail-brush of pure white, is separated from its nearest ally, $D$. deserti, by a group of small dark-tailed forms.

Under the genus Peromyscus, comprising the American white-footed mice, the mixture of species and subspecies fairly takes one's breath away. The same is true in less degree of Microtus and of numerous other genera throughout the Catalogue.

Sciuropterus volans is given as the name of the European Flying Squirrel and $S$. voluncella as that of the American. This, while in accordance with former usage, is unfortunate since the Mus volans of Linnæus, 1766 , is the Flying Squirrel of Virginia, as shown by Jordan and Bangs.

Under Sciurus douglasi five synonyms are raised to the rank of 'varieties.'

Under Sciurus aberti, S. castanotus [= castanonotus] Baird and $S$. durangi Thomas are given as subspecies. The former is a synonym; the latter a distinct species.

Under Sciurus arizonensis are included as subspecies the hardly distinct huachuca of Allen 
and several widely different species, as $S$. colliæi Richardson, $S$. hypopyrrhus Wagler and others. A curious freak in nomenclature is illustrated by this series, the majority of the 'subspecies' included under arizonensis antedating it by many years!

Coming to the Chipmunks, the author abandons his own earlier and, in the reviewer's judgment, excellent division of the group into Tamias and Eutamias and lumps them all under the former name. In arranging the species and subspecies of this perplexing group it is no wonder he is somewhat mixed, and that the forms are distributed without regard to their affinities. Thus pricei, at most a subspecies of merriami, is given full specific rank and placed between townsendi and macrorhabdotes. The latter, instead of ranking as a species, should stand as a synonym of quadrimaculatus.

The Spermophiles of the lateralis group (subgenus Callospermophilus Merriam) are placed in the genus Tamias, with which they have no close affinity.

Spermophilus sonoriensis, a subspecies of tereticaudus, is placed in a different subgenus! And tereticaudus and the closely related neglectus are wrongly referred to the subgenus Ictidomys.

In many instances Dr. Trouessart adopts the oldest generic name, as Coendu for Synetheres; Ochotona for Lagomys, and so on; but in many cases he fails to do this. Thus,

Coelogenus F. Cuvier, 1807, is antedated by Agonti Lacépède, 1799.

Lagostomus Brookes, 1829, is antedated by Vizcacia Schinz, 1824.

Myoxus Schreber, 1782, is antedated by Glis Brisson, 1762.

Platycercomys Brandt, 1844, is antedated by Pygeretmus Gloger, 1841.

Scirtomys Brandt, 1844, is antedated by Scarturus Gloger, 1841.

He uses also many preoccupied names. Among these are:

Arctogale Peters, 1864; replaced by Arctogalidia Merriam, 1897.

Echiothrix Gray, 1867; replaced by Craurothrix Thomas, 1896.

Hydrolagus Gray, 1867; replaced by Limnolagus Mearns, 1897.

Ictis Kaup, 1829; replaced by Arctogale Kaup, 1829.
Macrorhinus F. Cuvier, 1826; replaced by Mirounga Gray, 1827.

Wagneria Jentink, 1886; replaced by Bassariscus Coues, 1887.

The authority for Tylonyx, given as a synonym under Dicrostonyx, should be Schulze instead of 'Huth.'

Dr. Trouessart is not one of those who regards as sacred the original spelling of generic names. On the contrary, he accepts amended names in preference to the originals and in so doing operates at both ends, changing Pithecheir to Pithecheirus and Endecapleura to Hendecapleura!

A number of generic names are given erroneous dates. For instance:

$\begin{array}{lccccc}\text { Acomys } & \text { dates from } & 1838 ; & \text { not } & 1840 . \\ \text { Alticola } & \text { "6 } & \text { " } & 1881 ; & \text { " } & 1884 . \\ \text { Ctenodactylus } & \text { " } & \text { " } & 1830 ; & \text { " } & 1828 . \\ \text { Dolichotis } & \text { " } & \text { " } & 1819 ; & \text { " } & 1822 . \\ \text { Graphiurus } & \text { " } & \text { " } & 1838 ; & \text { " } & 1829 . \\ \text { Heterocephalus } & \text { " } & \text { " } & 1842 ; & \text { " } & 1834 . \\ \text { Nyctocleptes } & \text { " } & \text { " } & 1832 ; & \text { " } & 1835 . \\ \text { Rhombomys } & \text { " } & \text { " } & 1841 ; & \text { " } & 1843 . \\ \text { Tachyoryctes } & \text { " } & \text { " } & 1835 ; & \text { " } & 1834 .\end{array}$

Under Echimys and the amended form Echinomys the authorities and dates are badly mixed.

In the case of family names the rule of priority is not always followed. For instance, 'Lagostomidx Bonaparte 1837' is antedated by Chinchillidx Bennett 1833; and Coendidæ Trouessart is antedated by Erethizontidx Thomas.

Perhaps the oddest error in the Catalogue is the transposition of the Trinidad Opossum, Thylamys carri Allen and Chapman, to the Rodent genus Tylomys Peters!

The subfamily heading Murinæ is omitted, apparently by accident, and the resulting arrangement as printed puts Mus as a subgenus of Otomys !

A single new subgenus, Microlagus, is named. It is based on Lepus cinerascens Allen, a form whose relationship with $L$. trowbridgii is so exceedingly close that it is probably only subspecifically separable, and yet $L$. trowbridgii is placed in a separate subgenus (Sylvilagus Gray)!

A curious instance of persistent misspelling is the repeated occurrence of Vernon Bailey's name as Bayley, and of specific names based 
thereon as bayleyi. Similarly Reithrodontomys lace $i$ is spelled lacyi.

In dividing the work into parts it is a pity the publishers did not end the second part with the Carnivora instead of including the first 63 pages of the Rodentia. In binding by orders - the most convenient form for most uses-the volume on the Rodentia will have no title-page in front, but has one for the matter posterior to the $63 \mathrm{~d}$ page, where the $3 d$ fasciculus begins (page 453 of the whole Catalogue).

The reviewer is indebted to Dr. T. S. Palmer for calling his attention to a number of the errors in generic names and dates.

In two instances Trouessart imposes new names on forms distinguished but not named by previous authors, and in both instances modestly but wrongly credits the name to the previous author instead of himself. The cases in point are Vespertilio gryphus septentrionalis, attributed to Harrison Allen, and [Mus] sylvaticus var. noveboracensis, attributed to Erxleben, and placed as a synonym of Peromyscus leucopus.

The three parts now published comprise the Primates, Chiroptera, Insectivora, Carnivora and Rodentia and contain 760 genera and 4,085 species. Of these, 288 genera and 1,900 species are included in the single order Rodentia.

The Catalogue, in spite of its inherent imperfeations, is an extremely useful document and must be at the elbow of every student of mammals.

\section{Hart Merriam.}

Guide to the genera and classification of the North American Orthoptera found north of Mexico. By SAmuel HubBard Scudder. Cambridge, Mass., Edward W. Wheeler. 1897. Pp. 89 . Price, $\$ 1.00$.

Dr. Scudder began his entomological studies with the Orthoptera, and is still at work elab-orating the sub-families, genera and species with reference to a general work on the classification of the order. The little book before us is designed to serve as a Prodomus of the work, which we hope may be completed at a no distant day. As such it will be of great service to the student, since the families, subfamilies and genera are tersely and yet fully described. Besides these diagnoses there are elaborate tables for the determination of the families, sub-families and genera; the species not being mentioned.

In addition to the general bibliographical notes, those devoted to the families and the list of the literature are full and presumably exhaustive. The index appears also to be complete. The paper and printing are unexceptional.

It will be seen that the book will be indispensable to the student, as there is nothing like it in our entomological literature. That it has been prepared with thoroughness and care goes without saying. When will the time come when we shall have similar exhaustive manuals of the other orders of insects.

\section{A. S. PACKARD.}

\section{Les Ballons-Sondes de MM. Hermite et Besan.} çon et les Ascensions Internationales. Par WILFrid de Fonvielie. Bibliothèque des Actualités Scientifiques. Paris, GauthierVillars. 1898. 18mo, Pp. 112. Figs. 27. This brochure by my colleague, the Secretary of the Aëronautical Commission, is timely, since it is the first complete account of an important investigation in Europe. M. de Fonvielle is well fitted to write on the subject, for he is not only a distinguished aëronaut and the author of several books on ballooning, but sipce their inception he has been an advocate of 'ballons-sondes,' or 'ballons perdus,' as formerly they were derisively named.

When one of these exploring balloons, set free by MM. Hermite and Besançon, in No. vember, 1892, lost its buoyancy and fell to the earth there was obtained for the first time, from its minimum barometer and thermometer, the greatest height and the lowest temperature which had been reached. Fourteen of these small balloons having envelopes, generally of paper, filled with illuminating gas were liberated from Paris and most of them were recovered with their instruments recording the extremes of height and cold. MM. Hermite and Besançon, therefore, were encouraged to continue the exploration of the upper air with larger balloons made of goldbeaters' skin or of special silk, which they called Aërophiles. These carried continuously recording barom- 